\title{
Disrupting the transpacific: objects, architecture, war, panic
}

\section{J. M. Mancini}

To cite this article: J. M. Mancini (2016) Disrupting the transpacific: objects, architecture, war, panic, Colonial Latin American Review, 25:1, 35-55, DOI: 10.1080/10609164.2016.1180781

To link to this article: https://doi.org/10.1080/10609164.2016.1180781

曲 Published online: 05 Jul 2016.

Submit your article to this journal $\square$

Џll Article views: 239

View Crossmark data $\sqsubset$ 


\title{
Disrupting the transpacific: objects, architecture, war, panic
}

\author{
J. M. Mancini \\ Department of History, Maynooth University, Co. Kildare, Ireland
}

\section{Introduction}

In recent years, scholarship on transpacific exchange in colonial Latin America has expanded and deepened, particularly with reference to the trade of silver for moveable goods produced in Asia such as silk, porcelain and ivories, and the implications of that exchange for local cultural production both in the Americas and in the western Pacific. Although these emphases are understandable, they risk overshadowing another factor that also shaped the transpacific as a zone of interconnection and interactivity: war, and particularly conflict between Spain and one of its chief imperial rivals, Britain. The empires of Spain and Britain clashed frequently in the early modern period, and in the eighteenth century Britain's increasingly global approach to inter-imperial war repeatedly brought such conflict into the Pacific. During The War of Jenkins' Ear or Guerra del Asiento (1739-1748), for example, George Anson sacked and burned the town of Paita, in Peru, before crossing the Pacific and ultimately seizing the Manila-bound Nuestra Señora de Covadonga in June of 1743. And, only decades later during the Seven Years' War (1754-1763), British forces captured both the city of Manila and the Acapulcobound Santísima Trinidad in 1762 . To be sure, Britain's militarised turn to the Pacific did not signal an end to its attacks on more traditional targets: in 1762, British forces also took the city of Havana, and during every war in the century British naval ships and privateers attacked and seized Spanish vessels in the Atlantic (indeed, in 1779, one of Spain's first losses after its entry into the U.S. War of Independence was the urca Santa Inés, returning from Manila via the Cape of Good Hope). Thus, despite its geographical remoteness from, and other differences to cities in the Americas, Manila and its inhabitants shared an experience common to colonial Spanish American history in its exposure to war with Britain.

A full account of that shared history is beyond the scope of this essay, but a more limited consideration of Anglo-Spanish war in the context of a volume on transpacific exchange has two potential advantages, the first being that it adds a new dimension to the study of economic issues. On the one hand, analysing conflict allows the transpacific to be interpreted not only as a space for the circulation of silver and goods within the Spanish Empire (or between it and trading partners such as Chinese merchants), but also as a space in which sudden disruptions to that flow took place. For example, when Anson captured the Nuestra Señora de Covadonga, it was carrying the year's supply of silver destined for Manila: '1,313,843 pieces of eight, and 35,682 oz. of virgin silver' (Walter 1928, 349-60, 363). For the wide circle of people in the Philippines, colonial 
Spanish America, and Spain with interests in this shipment or the goods to be made or exchanged for it (or for those who had to labour to replace it), such a large and abrupt loss was surely of consequence. On the other hand, the inclusion of war in studies of Pacific exchange also allows, perhaps counter-intuitively, for moments of disruption within the Spanish imperial economy to be seen as episodes of interconnection or convergence between the Spanish imperial and British imperial economies-episodes, moreover, in which the sudden arrival of surplus into the British economy accelerated exchange between Britain and its trading partners and within Britain itself. Or, to put it more concretely, in Anson's hands silver that had been extracted and processed in Peru or New Spain and which normally would have been used (among other things) to buy Chinese goods which would have been sent to Acapulco and bought by consumers in New Spain (among other places), was instead used by Anson to buy Chinese goods (notably, a large porcelain service) destined for Britain-as well as to commission a host of British artistic and architectural products and services (such as the lavish up-scaling of his brother's country house, Shugborough Hall). In turn, recognising these intersections has the potential to influence wider debates in global history. For if, as the editors note, 'the importance of Spain's trans-Pacific exchange has been largely eclipsed by studies of the later empires of the Dutch and the British,' it is also the case that those studies of the British Empire-and the intersecting, voluminous literature on British consumer culture-tend to ignore not only Spain's transpacific exchange but even the very existence of the Spanish Empire, let alone to recognise Anglo-Spanish interaction, or takings from Anglo-Spanish conflict, as factors in the British 'pursuit of luxury.'

Pairing the analysis of war with the analysis of exchange can also shed light on war itself. Here, two topics will be explored. The first is the disrupted circulation of a category of objects-for example, maps, pilots, and manuscripts-whose primary value lay not in their monetary or commercial worth, but in the intelligence they conveyed. Second, these processes involving moveable forms will be linked to processes involving immovable forms such as landscape and architecture. Including immovable forms is important because war subjected them to the same processes of physical disruption and transfer enacted upon silver and moveable objects, as British personnel seized building materials or pried pieces from structures for military or personal gain. But the war-and the security panic that followed the British capture of Manila-also set in motion longer-term architectural processes. Chief among these was the radical reconfiguration of Manila's built environment, which before the invasion had been characterised by the close proximity of the walled city to a ring of extramural towns inhabited by multi-ethnic populations and strongly influenced by the Catholic religious orders. During a decades-long period of extramural clearance and intramural fortification, this urban form was replaced with a walled city starkly partitioned from its suburbs by a blank security crescent emptied of buildings and people.

\section{2}

Let us turn, then, to the 1762 British expedition to Manila, which intersected with events in the Americas in at least two ways. First, as noted, the expedition to Manila was undertaken together with an attack on Cuba by British forces. Second, the two British attacks of 1762 
were methodologically interconnected in the sense that, in both cases, British personnel prioritised not the permanent transfer of territory-indeed, after the war, captured territories in Cuba and the Philippines reverted to Spanish rule-but rather, the way that war could engender surplus transfer. To be sure, in this respect the Havana and Manila expeditions (and, perhaps, most British actions against colonial Spanish America) were not only like each other, but different from the kind of war Britain waged against its other rivals. As historians have intensively documented, for instance, Britain's war against France in North America during the same conflict was a 'contest for continents' aimed towards permanent territorial gain. ${ }^{2}$ As I have argued elsewhere (Mancini 2011), Britain's specialised approach to Anglo-Spanish conflict owed much to Anson's influence. After his return from the Pacific, Anson became a celebrity, whose many attendant images, objects, and texts not only spread his fame and popularity, but legitimatised and advocated the approach to imperial conflict he had taken in the temporary seizure and looting of Paita and the capture of the Covadonga. As important, his exploits fuelled his rapid rise through the naval hierarchy, giving him both power and the ability to dispense patronage. This culminated in his service, as First Lord of the Admiralty, in the single most influential naval position in the British Empire-a position from which he supervised both the Havana and Manila expeditions.

In the Philippines, this prioritisation of surplus transfer over permanent territorial gain was manifest in the zeal with which Admiral Samuel Cornish, leading the British fleet, pursued the taking of prize. Indeed, even before the expedition had succeeded in its mission to capture the city, Cornish diverted two of his ships away from the task to chase the Philipina, due from Acapulco with a 3-million dollar cargo of silver. In his letter to Anson, Cornish represented this decision through an appeal to Anson's own history in the region that cast Cornish's leadership (and specifically, his decision to assign one of Anson's former subordinates, Hyde Parker, to this task) almost as the expression of an Ansonian will:

I gave Captain Parker an order to command the Panther, as she was a Clean ship, and joyn'd the Argo with him to go in quest of the Galleon St. Philippina who was at Cajayagan between the Bocadera \& Cape Spiritu Santo the $10^{\text {th }}$ of Sept.; and proposed remaining there till the Monsoon was broke up; As Capt. Parker was with your Lords[hi]p and is very well acquainted with those seas I have the most sanguin[e] hopes of his success. ${ }^{3}$

Cornish turned out to be right: after the war Parker would himself interpret his own actions specifically in these terms, when he wrote that he had 'endeavoured to follow the footsteps of my Noble patron and excellent friend [Anson] whose zeal for the honour of his Country and affection to the sea Service ought to endear his memory to every sea officer. ${ }^{4}$ Cornish also correctly predicted Parker's success in the quest to replicate Anson's seizure of the Manila galleon. Although Parker did not find the Philipina because its captain, having been alerted to the British attack, had beached it on the Pacific shore of Luzon (thus enabling the leader of the resistance to the invasion, Simón de Anda y Salazar, to provision and pay his supporters), on 30 October the Panther and Argo did capture the Acapulco-bound Santísima Trinidad (Dreaper 2006).

Once the city was captured, British personnel continued to prioritise the transfer of surplus, not only gaining the promise of a ransom of four million dollars through the agreement of terms of capitulation, but also thoroughly looting Manila's public buildings 
and religious houses. As suggested above, this looting targeted both moveable goods (for instance, silver liturgical objects), as well as elements of the city's architectural fabric. Indeed, even months into the occupation, British officers were attempting to hold to ransom the bells of the convent of Santa Clara; when that failed, as the nuns recounted, 'the English proceeded in the extraction of the bells of Sta. Clara with such vigour that they did not even spare the small one from the cloister. ${ }^{5}$

This prioritising of material gain paralleled events in Havana, where British officers employed both legal and extralegal means (if not looting) to do so. Hence even while Britain returned Cuba to Spain via the 1763 Treaty of Paris, British personnel retained their individual gains. The expedition's leading naval officer, Admiral George Pocock, for example, received 299,993 dollars and $2 \frac{1}{2}$ reales $(£ 122,697)$ - within a naval share that totalled 899,980 Spanish dollars (approximately $£ 375,000$ ). This was distributed amongst 14,499 men-including 42 captains who each received 4821 dollars $2 \frac{1}{2}$ reales (nearly two thousand pounds) (Syrett 1970, 297-98; García del Pino 2002). This, in turn, was matched by another $£ 122,697$ paid out to Pocock's ground forces counterpart General George Keppel, the $3^{\text {rd }}$ Earl of Albemarle-and another 899,000 distributed to the ground forces. And even beyond that, Albemarle also extorted a substantial 'present' of an additional hundred thousand dollars from the Bishop of Santiago de Cuba, D. Pedro Agustín Morell de Santa Cruz. ${ }^{6}$

\section{Divergent fortunes}

The capture of Manila did not leave the city permanently in British hands, but it, and the seizure of the Santísima Trinidad, inflicted significant collective and personal losses nonetheless. In July of 1763, shortly after the cessation of hostilities, the engineer Miguel Antonio Gómez described conditions in the Philippines to the Secretary of State for the Indies, Julián de Arriaga: 'Commerce completely annihilated; temples robbed, the houses destroyed, possessions lost and the families without shelter, having lost their Fathers, Husbands, and Brothers, some to the blade of the sword of the Englishman, and others to the cruelty of bandits, and faithless Indians, and to agitators.' Indeed, Gómez spoke from bitter personal experience, having lost in the conflict 'many memoirs and observations that I had gathered, regarding the Geography and natural history of these lands'-and, in the captured Santísima Trinidad, a letter that (Gómez assured Arriaga) the governor had written on his behalf after elevating him to the rank of Captain of Infantry and Ordinary Engineer, asking for Arriaga's approval to increase Gómez's pay. ${ }^{7}$

Gómez was not alone in this experience of wartime loss. The oidor Pedro Calderón Henríquez, for example, had been on board the Santísima Trinidad en route to Acapulco when it was captured, and his treatment caused him to present a strongly worded protest to the East India Company's governor of the occupied city, Dawsonne Drake. Several aspects of this episode outraged Calderón Henríquez, who lost a personal fortune of thirty thousand dollars in the affair: his detention in Cavite for nineteen days; the breach of normal Spanish and British protocols that would have provided, during the prize adjudication, for his maintenance according to his 'Rank \& quality'; and the fact that, even though no inventory had been taken, 'the Admiral [Cornish] has declared himself a party in ordering the ship to be unladen, and the Jewells found aboard her, to 
be disposed [of], without giving notice to the persons concerned; my Desks, bundles, \& chests were broken open, and many things of great Value taken out of them and landed at Cavite.' This, Calderón Henríquez insisted, 'transgressed against all the ordinances of the Marine. 8

Beyond personal losses of moveable goods, others noted the detrimental effects of the British way of war on Manila's built fabric-for example, their undoing of royally decreed building projects that had been under way (and in some cases were nearly complete) at the time of the invasion, such as works on the Royal Hospital. Thus in June of 1764, the interim Governor, Francisco Javier de la Torre, recounted to Arriaga that work had been 'cracked by the reciprocal fire of war' and damaged by being left uncovered during the conflict. But he also emphasised the harm inflicted by the predations of English soldiers: 'While they stayed in this city,' he wrote, 'the English took the collected [building] materials' and applied them to 'their defence and fortification, taking apart the offices in the Hospital that were being repaired.'

In contrast to these stories of loss, humiliation, and regression, several of the higherranking British officers who participated in the Manila expedition experienced lavish gains. For example, Hyde Parker received a $£ 10,000$ share of the prize from the Santísima Trinidad, including a large number of Chinese porcelains such as a pair of Kangxi-era jars with domed covers, decorated in iron red and gilt (Melford Hall, Suffolk, England). Moreover, although Parker was the son of a Church of England clergyman whose family tree included the royalist Bishop of Salisbury, Alexander Hyde, he also held on to another kind of object that would have been common in eighteenth-century Spanish America but very rare in eighteenth-century Britain: Philippine-made Catholic devotional figures. Hence the estate bought by Parker's son, Melford Hall, still displays a large ivory processional figure of the Santo Niño or Holy Child and a figure of the Virgin of the Immaculate Conception (see also [Garnett] 2005). Moreover, Parker's prize-taking also facilitated the further commissioning and acquisition of works of art and architecture in England by Parker and his family-including both Asian objects such as a set of armorial china with the Parker arms, and works by English makers. Thus, Parker's emulation of Anson extended beyond his wartime actions, to his post-war use of the proceeds of war.

British enrichment from temporary Pacific conquest extended beyond the acquisition of valuable objects to the making of fortunes. With his share of the Santísima Trinidad prize, for instance, Cornish was able to acquire a landed estate in Bedfordshire in 1765, which included the manors of Sharnbrook, Tofte, and Temple-Hills (Lysons and Lysons 1908, 130-31); with the support of the duke of Norfolk, he gained election as MP for Shoreham, and in 1766, he was made a baronet (Laughton rev. Tracy). And the leader of the ground forces, William Draper, was able to overcome years of worries about money. As his biographer James Dreaper notes, these worries had been so acute that, after the successful defence of Madras against the French in 1759, Draper had exclaimed to a friend and fellow officer: 'Pox take the poverty of these Frenchmen. I shall not be able to scrape up a winter's play at Arthur's.' In contrast, he was able to leave Manila with a $£ 5000$ draft drawn upon the East India Company, which had assumed control of the city after its capture. With this, Draper was able not only to avoid penury, but to build a spacious country house near Bristol he called 'Manilla Hall,' to erect an obelisk and sarcophagus commemorating his superiors and subordinates, 
and to commission a handsome portrait of himself by Thomas Gainsborough (ca. 1765; Fine Arts Museums of San Francisco). ${ }^{10}$

In both of these aspects - the British legacy of gain and the transformation of that gain into art and architecture-the Manila campaign once again intersected not only with Anson's prior campaign in (and return from) the Pacific, but also with the Havana expedition. As noted, the capture of Havana brought about a vast payout for Albemarle - and for Albemarle's younger brother, Augustus, Viscount Keppel, a former Pacific subordinate and lifelong protégé of Anson's who received a $£ 25,000$ share. After the capture of Havana, at least some of the Keppel family's windfall went to commission the FrancoBritish artist Dominic Serres (1722-1793) to make a series of paintings of the city's capture and occupation, including The Piazza at Havana (ca. 1765-1770; National Maritime Museum, Greenwich, London). Thus while the expedition did not permanently bring the 'real' city of Havana into the British Empire, it did bring representations of it into the art and homes of the imperial elite-just as the Manila expedition built 'Manilla' into Draper's 'Manilla Hall' (and, even with the demolition of that structure, into Bristol's 'Manilla Road'). ${ }^{11}$

\section{Insecurity}

In a sense, then, the Manila expedition-and, more specifically, the British pursuit of a method of warfare that prioritised material transfer-disrupted not only the individual material fortunes of Manila's people and its collective built fabric, but also what might be thought of as the 'balance of fortune' between Spain's subjects in Manila and their British counterparts. Yet, the Manila expedition also had another important disruptive legacy: the sudden collapse of Spain's superior knowledge of the transpacific, including Manila itself, and a corresponding rise in British intelligence.

This convergence in intelligence was also a product of British methodologies during the war. Recall that, in this era, sensitive information could be embedded within unique material forms (such as manuscript maps and pilots) whose viewing, copying and circulation could be controlled, and emplaced within specific repositories to which outsiders did not normally have access. British officers knew this, and used armed conflict as a tool to gain access to its rivals' 'intelligence objects.' Hence, during his cruise for transpacific prize, Anson specifically sought out maps and other papers that could be obtained from Spanish vessels, as well as objects and materials of monetary value; so, too, in the Manila expedition of 1762, when British personnel engaged in the large-scale taking of manuscripts, images, rare printed books, and other objects which archived, condensed, and represented geographical, hydrological, historical, and other knowledge of Manila, the Philippines, and the wider transpacific.

For obvious reasons-including Draper's vehement campaign to deny that looting had taken place-this hoard of 'intelligence objects' is somewhat difficult to catalogue. Nonetheless, a number of items in the British Library (and in other repositories including Indiana University's Lilly Library) may be identified as having definitely or likely exited Manila as a result of the expedition. One example is a manuscript in the British Library that had belonged to Manila's Augustinians, the "Libro de Consultas," or Chapter-book of the Convent of St. Paul at Manila; 10 Aug. 1751-14 Dec. 1761.' As a helpful note in pencil explains, 'This M.S. which affords a curious illustration of the [...] government 
of a monastery in the Spanish Colonies was part of the plunder of Manila when that town was sacked by the English Squadron under the command of Sir Wm Draper. It belonged [...] to [Alexander] Dalrymple hydrographer to the Admiralty. ${ }^{, 12}$

Similarly, the British Library also possesses a 1751 manuscript made through the collaboration of Francisco Alegre, a Manila pilot, and Joseph de la Concepción, rector of the Augustinian Recollects of the Province of San Nicolas de Tolentino-a province that, like that of the Augustinians, had registered complaints of pillage with the British authorities. In this case, it is easy to grasp why the manuscript would have appealed to the intelligence(and beauty-) seeking looter, as it contained not only Concepción's 'account [...] of the Origin, Progress, and state of said Province, and of the Religious, who have worked in it since the year 1606, until the present year of 1751,' but also Alegre's manuscript maps, each coloured in blue, red, and other shades, backed with an undyed woven fabric, and finished with a blue-dyed woven edging. These, in turn, contained important navigational data such as the location of anchorages, forts, and rocks. ${ }^{13}$

Rare books in the British Library appear to tell a similar story. An example is its copy of Admiral Joseph González Cabrera Bueno's Navegacion especulativa y practica. Like the Concepción-Alegre manuscript, this work was also the result of collaboration between religious and military personnel, as it was published at Manila's Franciscan convent of Nuestra Señora de los Angeles in 1734. Because this is a printed work, it is somewhat more difficult to assert that it passed into the British Empire in 1762-a few other copies of it do exist in libraries beyond the boundaries of the former Spanish Empire. However, the British Library's vellum-bound copy has on its title page the signature of the Jesuit polymath Pedro Murillo Velarde, a long-time Manila resident (Figure 1). This suggests that the volume had been Murillo Velarde's personal property and thus had resided in one of Manila's Jesuit institutions before arriving in Britain. Moreover, there is a plausible vector for the transfer of the Navegacion especulativa y practica to Britain as a result of the expedition. In addition to the devotional ivories and porcelains Parker acquired from the Santísima Trinidad, he also possessed upon his return to Britain 'books charts and Manuscripts which I collected during my service in the expedition against Manilla.' These included 'the Cronicas de San Gregorio,' a reference to the Franciscan province, works by 'the Jesuits Colin [and] Murillo [Velarde] and some other writers,' and 'the Manuscripts of Don Antonio Porez Gil, the Admiral Cabrera Bueno[,] Don Manuel Corea, and the Spanish printed instructions to the Generals of ther Galeons.' Although Hyde Parker described his Cabrera Bueno as a 'manuscript,' this may possibly be attributed to its binding in limp vellum, a practice that was commonly applied to Spanish printed texts of the eighteenth century but that in England was by that time more frequently reserved for manuscripts. ${ }^{14}$

To get a sense of what was potentially at stake in the transfer of such objects, it is also necessary to reflect upon the state of British knowledge of (and capacity to represent) Manila, the Philippine archipelago, and the transpacific. Here it may be said that, prior to the 1762 expedition, British capacity in this area had been quite deficient compared to their knowledge of the Atlantic or ports in Spanish America. William Hacke's 1700 map, 'Luconia,' had only indicated the very general location of Manila, omitting the eastern reaches of Luzon, the Embocadero de San Bernardino, and any other details that would facilitate an approach from the Pacific. Moreover, the map of Manila that 


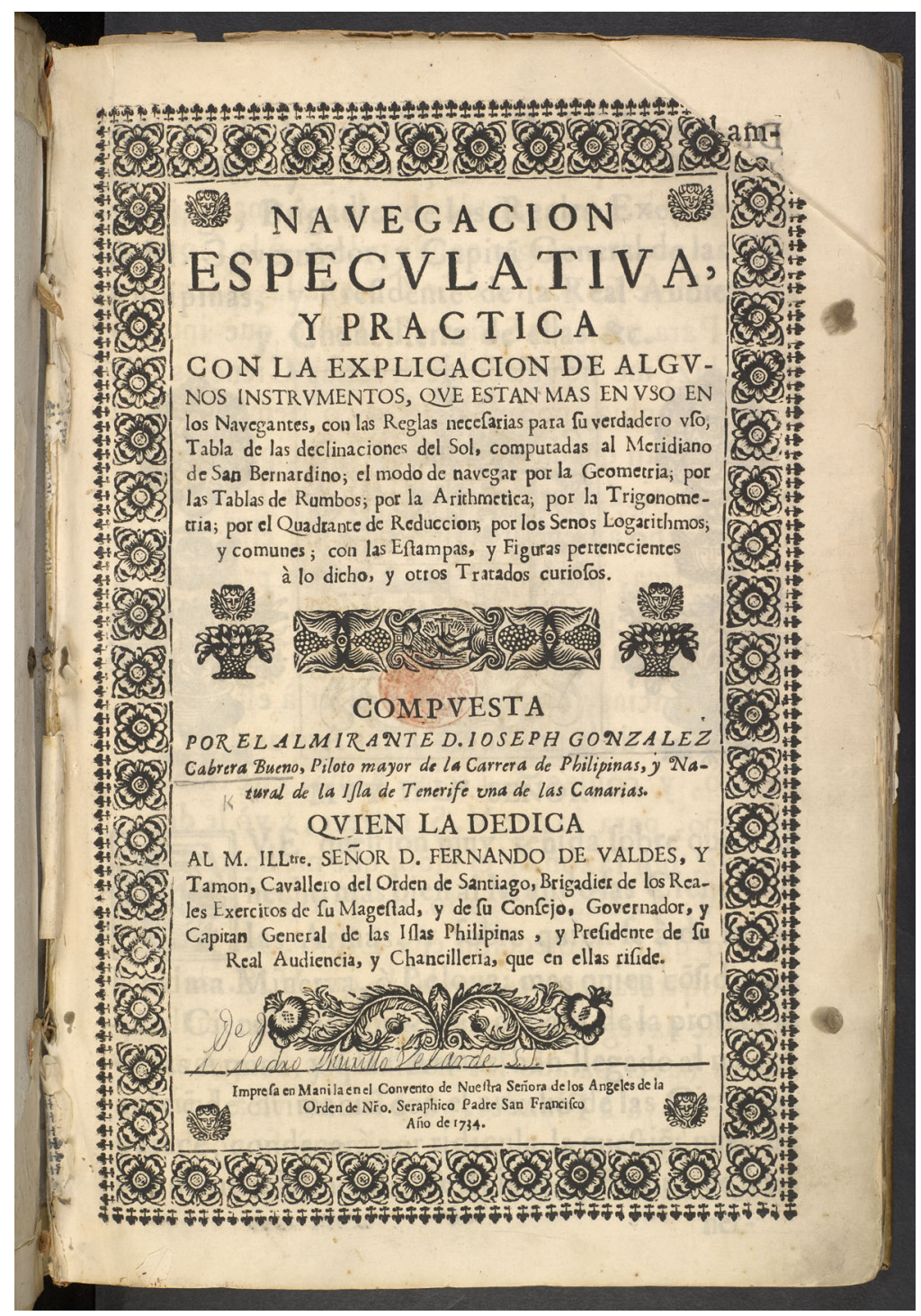

Figure 1. D. Joseph González Cabrera Bueno, Navegacion especulativa y practica, 1734. (c) British Library Board, 8805.g.2.

appeared in the lavishly illustrated, and generally highly detailed account of Anson's transpacific expedition, Richard Walter's 1748 Voyage round the World, had done little more than gesture towards the general shape of the city. And when British mariners had sailed to Manila from India in 1762, they had not drawn upon British charts to make their approach. Rather, they seem to have relied on a single Spanish image: 'Murillo [Velarde]'s chart of the Philippines' (his 1734 Carta hydrographica y chorographica de las Yslas Filipinas). Indeed, Parker insisted that this map had been taken by Anson himself from the Covadonga, and that Anson had 'sent [it] out by the Argo' for use in 1762. ${ }^{15}$ 
The Manila expedition dramatically altered these circumstances. Suddenly, British draughtsmen had the chance to observe the city and bay of Manila directly, and gained the 'opportunity of proving' Murillo Velarde's map against the features it depicted (Parker 'found it drawn with great exactness and fidelity'). But, as important, their seizures during the campaign also gave British officers durable access to a wealth of information that had already been synthesised and represented in visual, narrative, and tabular format. Cabrera Bueno's Franciscan-published volume, for example, contained derrotas for the route across the Pacific between Acapulco and the Philippines (and between Spain and the Philippines via the Cape of Good Hope, Mozambique, and Malacca); the west coast of the Americas from Cape Mendocino to Acapulco, from Panama to Acapulco, and from Panama to Callao; and for the treacherous westward approach into Cavite from the Pacific via the Embocadero de San Bernardino. ${ }^{16}$

The British were also inclined to translate and re-synthesise that information in ways that advantaged their empire. Hence after his return Parker wrote, of the 'books charts and Manuscripts which I collected during my service in the expedition against Manilla,' that the 'principal object of my design was from these materials to form a directory for the Navigation of the Archipelago'-a task which was desirable because 'the navigation coasts and productions of the Phillipine [sic] Islands are matters so little known amongst us that I conceive I cannot employ my leisure hours more to the public advantage than by giving the best account I can of them,' and because, 'had the Geography and strength of these Islands been better understood before our late expedition I am perswaded the success of it might have been more complete.' And, with Cabrera Bueno's volume in his possession, Parker was able to produce new accounts in English of the Pacific approach to Cavite via the Embocadero, and of the Pacific coast of North America from Acapulco to Mendocino. This had the potential to facilitate a British assault on the Philippines via the Pacific, instead of from India, and to assist a British campaign to secure new California, which was appearing on British maps as 'New Albion discover'd by Sr. F. Drake 1578. ${ }^{17}$

Similarly, Dalrymple appreciated the usefulness of abstracts of voyages 'from the Philippine Islands to New Spain, made in the years 1699-1740; from originals in the public archives in Manila.' These presented him with a catalogue of detail regarding the latitude and longitude Spanish vessels had followed along particular voyages; the dates they had embarked, landed, and sighted certain landmarks; the kinds of things that they had observed in addition to land, such as birds, wood, seals, or seaweed; and the characteristics of various coastal features-all of which exposed both the complex mechanics of the transpacific crossing and the likely location of Spanish ships en route. Hence after making annotations in the margin of these extracts, Dalrymple compiled his own manuscript in English of extracts of the Spanish abstracts. ${ }^{18}$

The intelligence revolution wrought by the Manila expedition also exacerbated risks to Manila itself by greatly simplifying the process whereby British actors identified and represented its buildings, thoroughfares, and points of weakness. Consider, for example, another item that circumstantially appears to have entered British hands through wartime seizure: Antonio Fernández de Roxas's 'Topographia de la ciudad de Manila, capital de las yslas Philipinas' (Figure 2). This incredibly detailed image was far too comprehensive to have been circulated in Britain before the conflict: for example, the then state-of-the-art American Gazetteer, published just as the Manila expedition was being launched, appears to have drawn its information on Manila-which, tellingly, appeared 


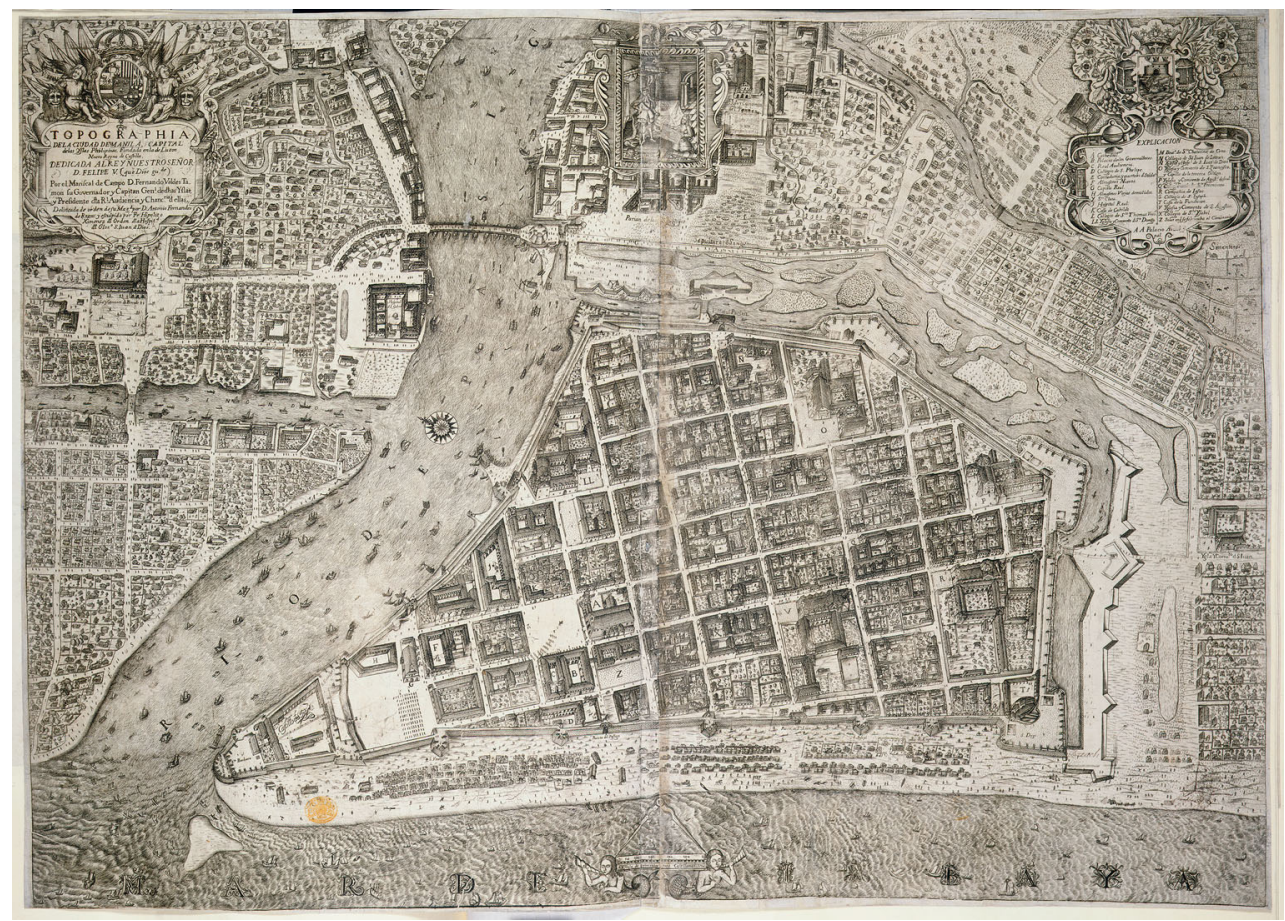

Figure 2. Hipólito Ximénez after Antonio Fernández de Roxas, Topographia de la ciudad de Manila, capital de las yslas Philipinas, ca. 1739.

(c) British Library Board, Maps K.Top.116.40.

in the Gazetteer's entry for Acapulco-from Anson's map. Hence, it asserted that 'at the beginning of the last war [Manila] was only an open place, its principal defence being a small fort.' Further, the Roxas map was lodged in King George III's topographical collection in sequence with the first British-drawn map of the city. And finally, it bears the inscription, in English, of the location of British batteries and the 'Breach' of the city walls at Bagumbayan. This suggests the Roxas topography may have been used by returning officers to present an account of the expedition to officials in London. Indeed, it is not too much of a stretch to imagine this materially enhanced account of British victory in the Pacific being made by Cornish's representative, Richard Kempenfelt, whom Cornish sent 'with my dispatches, and [who] will have the Honour to present to you some Coppar [sic] Plates of the Philippine Islands, that were found in Manila. ${ }^{19}$

To be sure, observers in the Spanish Empire would not have known precisely what British officers were doing with the intelligence objects they had taken from Manila's archives or the Santísima Trinidad. Nonetheless, even during the war they inferred from British actions a desire for further conquests. Thus Gómez implored Arriaga in 1763:

to repair the breaks that the Capital Manila, and its dependencies suffer, to assure its future conservation, and stem the advances that the English are making in these parts [...] I find myself feeling even that the English, after the taking of Manila, informed themselves of the individual transits that there are from the Port of Acapulco to the Capital Mexico, perhaps to install themselves in that Reign; in addition to notoriously making clear to me that in the year just past 7 English frigates left Jolo, 5 to reconnoitre the coasts of New 
Spain, and 2, for the discovery of the Reign of the South, the Salomon Islands, and lands of Fernando Gallego [...] if they extend their Conquests to these parts there will not be a single point of repose in all of the Coasts of the Americas.

As this suggests, even though the British expedition to Manila originated from India, Gómez imagined the future threat posed by Britain in expansively transpacific terms. ${ }^{20}$

Moreover, British actions even after their withdrawal from Manila gave credence to the spectre of continued British belligerence. In mid-1764, John Byron-another Anson alumnus-made the first British circumnavigation since Anson's, claiming the Falkland Islands along the way. As Geoffrey Rice argues, in this context both Spain and France took the view that Britain might recapture Manila, leading Spain to cancel the annual sailing in 1766 (Rice 1980). Such an assault never materialised, but even as late as 1796, Whitehall still contemplated attacking the city from India, if not via the transpacific: when peace between Napoleonic France and Spain sparked yet another Anglo-Spanish War, the administration of William Pitt the Younger (1783-1801; 1804-1806) hatched a plan, proposed through the Secret Committee of the East India Company, for an expedition 'to dispossess the Spaniards of Manilla.' ${ }^{21}$

\section{The breaking and remaking of Manila}

Following the calamities of 1762, the administration of Carlos III pursued a broad-based programme of securitisation on both sides of the Pacific and in the zone around Havana. This securitisation had many dimensions, but among them there was a strong attachment to the built environment as an instrument of security. Thus in the eastern Pacific, building projects were pursued such as the establishment of a new naval base at San Blas and the construction of Franciscan missions in new California.

Less familiar, but as profound, was the transformation of Manila. There, the British invasion unleashed a post-war security panic, promoted by military engineers and by royal officials. By encouraging their superiors in Spain to attribute the fall of Manila to spatial and material defects in its form - and to see continued risk in that form-these officials gained permission significantly to amplify the walled city's fortifications, while razing historic buildings and clearing neighbourhoods in the extramural corridor. This process disproportionately affected both the multi-ethnic inhabitants of towns such as Bagumbayan (which was home, as Concepción put it, to 'Españoles, Yndios, Sangleyes, o Chinos, Criollos, Morenos, Negros, y Castizos de todos ellos') and the religious orders. ${ }^{22}$

To be sure, this dynamic relationship between insecurity and architectural destruction -and even architectural destruction in Extramuros-was not new at this time. As Dana Leibsohn has written, during a panic caused by fear of a possible invasion by the Chinese military leader Koxinga in 1662, 'the Japanese residents of Manila [...] with the Spaniards and $[. .$.$] indigenous allies [...] dismantled all major stone structures outside of, but close$ to, the city walls. By destroying these buildings, they reasoned, Koxinga and his men would be denied strongholds from which to attack the city. Churches in Dilao, the Parian, and Bagumbaya, the country houses of the Spaniards, and the Hospital de los Naturales (San Lázaro) were all taken down' (Leibsohn 2014, 242). And, only decades before that in 1642, when faced with the threat of attack on the city by the 'Dutch enemy,' the governor Sebastián Hurtado de Corcuera ordered the destruction of the church and 
convent of San Juan Bautista de Bagumbayan over the objections of the Augustinian Recollects, who insisted that if the Dutch came 'the Religious themselves would mount the Walls, with their linstocks, and help the Artillerymen to pull down the Convent. ${ }^{23}$

The difference is that these seventeenth-century security panics were generally shortlived, and followed by periods of reconstruction; for example with the support of city officials, the Recollects were able to regain control of the demolition site in Bagumbayan, obtain funds to rebuild, and return by $1652 .{ }^{24}$ Hence before 1762 Manila retained, or regained, a composite urban form that brought extramural towns almost to the city walls. And, as a corollary, the retention of this built form also meant that the social and political characteristics that attended that form also persisted. One of these, again observed by Leibsohn, was the fact that the 'boundary between Intramuros and Extramuros was porous in lived reality' (Leibsohn 2014, 236) - a permeability and flow whose persistence into the eighteenth century is evocatively suggested by Roxas's 'Topographia de la ciudad de Manila,' with its depictions of people coursing on foot, in boats, and sometimes in carriages along the Calzada, through the wetlands of San Lázaro, and over numerous bridges including the bridge over the Pasig, the bridge emanating from the Parián gate, and the gate linking the walled city to Bagumbayan. Another characteristic, also discernible from Roxas, was the contiguity between the intramural compounds of the religious orders and their extramural parishes. From the vantage point of Nuestra Señora de los Angeles, for example, the Franciscans would have been able to take in a panoramic view of the town of Dilao-an extramural town initially established as a Franciscan parish for emigrant Japanese, but by the eighteenth century home to a complex mix of people similar to Bagumbayan's-and likely see their church and convent there.

In contrast, the security panic sparked by the British occupation fuelled a period of breaking and remaking that (despite periodic interruptions) persisted for half a century. And, although the U.S. invasion would spark another radical transformation to Manila's urbanscape that-among many other changes-saw significant rebuilding in the zone beyond the walled city, for the rest of the period of Spanish rule Extramuros remained a security zone to which people, dwellings, churches, and hospitals did not return.

\section{Panic}

After the war, it was only natural that those with a stake in the rule and defence of Manila should seek explanations as to what had gone wrong, but two substantially different and competing narratives emerged to explain the failures of security that had taken place. One account was provided by the Franciscan provincial Roque de la Purificación, one of several religious whom Anda had enlisted for support in the campaign against the British, who wrote to the king in July of 1764 from his convent in Dilao. In it, he repeatedly emphasised the willingness of religious and indigenous people to fight the British-in sharp contrast to the city's Spaniards. Thus he offered the following chilling and accusatory narrative:

With a rude breach the enemy took the Plaza by assault the fifth day of October, and found it so helpless, and the facade of the rampart so deserted, that not one Soldier could witness the scene of how the English mounted it. So much terror and horror had already come to us, my Lord, that the previous night, seeing that the breach was becoming practicable, and that the cannons of that Bastion were being lost because they were falling into the ditch, the Religious 
of all the Communities, they alone, with the Natives, dragged themselves to the safest part with the intention of covering the breach with timber, sandbags, and other bits of wood, but they were impeded by the Engineer, who said that it was solely his job to do these repairs. Because they found no resistance they occupied all of the posts of the Rampart, and were picking off people in the streets, this forced the Indians of the garrison to run in all directions. And in this way, many of them drowned in the River, fleeing the fire coming from the Wall.

As this suggests, the Franciscan's account put human failure-and specifically the failures of 'Soldiers,' 'the Engineer,' and other Crown personnel charged with the city's defence-at the heart of the fall of Manila. ${ }^{25}$

Not surprisingly, engineers and Crown officials presented an alternative version of events, highlighting instead how the city's problematic urban and architectural form had undermined (and continued to threaten) its security. Both de la Torre and Gómez promoted this materialist interpretation, emphasising the detrimental role played by two extramural churches that the British had occupied in their assault on the city walls. From this example, de la Torre extrapolated the security risk posed by other extramural churches. 'The English destroyed both Churches of S. Tiago and Bagumbaya, leaving only a confused pile of ruins,' he wrote to Arriaga in July of 1764, 'but on the same shore, within Cannon's reach, remain the Churches of la Hermita, and Malate, and by land, skirting the city are the Churches of San Lazaro Dilao, San Miguel, [and] that of the Parián of the Sangleyes, all within rifle range [of the walled city] and also the Church of Binondo, excessively built for its strength and outsized grandeur, and the Hospital of San Gabriel which is a rifle shot from the Wall, and the Church of Tondo[.]' With this 'circle of extramural strongholds,' de la Torre warned, 'the City will always be exposed from its foundations in any Invasion to being taken by the Enemy.'

As this indicates, those who attributed culpability for the city's fall to material deficiencies tended to project that risk forward, and to argue that Manila's future protection depended upon profound changes to its built fabric. Hence in 1764 Gómez, under de la Torre's patronage, submitted a proposal to the king outlining how architectural and engineering works would put the city into a 'state of defence' (Figure 3). This proposal included a written report, but also a detailed visual 'Plan of the plaza of Manila and Archipelago of San Lazaro' which presented the proposed changes in succinct visual form (and which invited the king to visualise both the defective, existing city and its transformed, secure alternative) by rendering the features of the existing city in dotted lines, while indicating 'with solid lines a new plan of fortifications to place the said plaza in a state of defence.' As Gómez put it in his accompanying account, a 'simple inspection of [his] plan' could express much more than all of the 'wordy reports could do. ${ }^{27}$

Although this trope was not new, Gómez's appeal to the plan's visual simplicity perhaps deflected attention from how radical it was in two, intersecting respects. First, it called for a reimagining of the city not in the way that previous mapmakers, notably Roxas, had represented it - that is, as a living city thickly inhabited by people in motion-but rather as an inert composite of structures and spaces. Second, it proposed not only new construction in the enhancement of fortifications, but also architectural destruction. Thus in Gómez's cartographical vision, the solid lines of the new city protruded into and overwrote existing structures, settlements, and thoroughfares. Among these overwritten places-all depicted in Roxas's topography as thronged with people, but in Gómez's plan as empty-were 


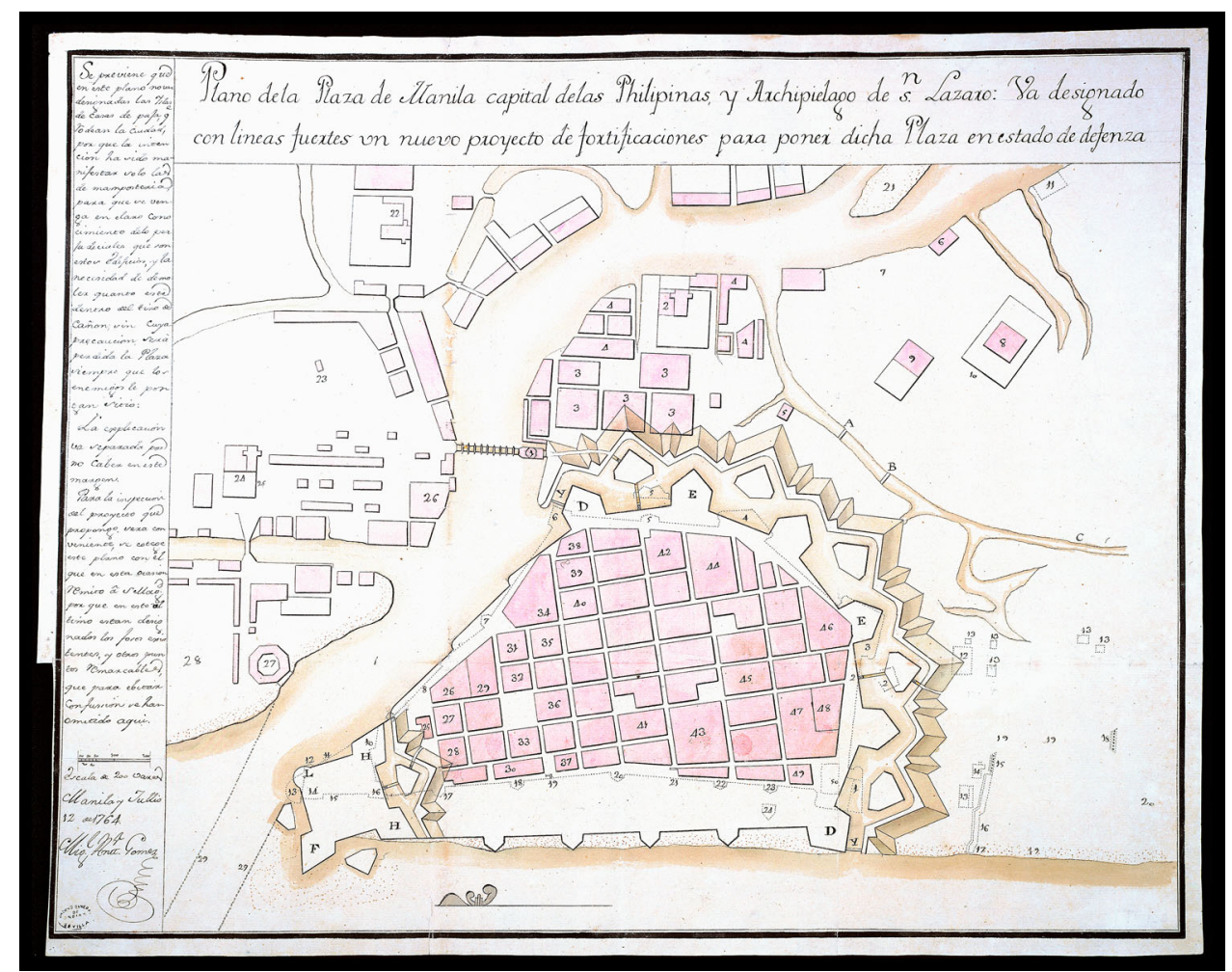

Figure 3. Miguel Antonio Gómez, Plano de la Plaza de Manila capital de las Philipinas, y Archipiélago de Sn. Lázaro: Va designado con lineas fuertes un nuevo proyecto de fortificaciones para poner dicha Plaza en estado de defenza, 1764. Spain. Ministerio de Educación, Cultura y Deporte. Archivo General de Indias, MP-Filipinas, 160.

buildings in the Parián (which was home to a substantial Dominican complex as well as the homes, businesses, and cemetery of its Chinese community); much of the part of the Pueblo de Dilao located inside the Estero de San Lázaro; most of the Pueblo de Bagumbayan (including 'the burnt Church and Convent of San Juan de Bagumbayan, belonging to the Recollect Fathers, whose sacristy the British occupied after demolition'); and the city's two circum-mural routes: the waterway of the Archipelago de San Lázaro and the Calzada. Moreover, in his accompanying report, Gómez advocated architectural destruction well beyond the removal even of the overwritten structures: 'It might be [...] convenient,' he wrote, 'for your Majesty to demolish the Churches, and the neighbourhoods that ring the Plaza, and that are located within range of Cannon shot. ${ }^{28}$

As this indicates, although Gómez's plan clearly carried immense social, cultural, and political implications, his case for interpreting Manila's vulnerability in this way-and for using architectural destruction to mitigate Manila's past and present weakness-largely depended on spatial arguments regarding the city's form. Hence he repeated de la Torre's alarmist phraseology describing the churches' location as 'only a shot away' from the walled city-'a tiro de fucil del Muro,' 'no sale del alcanze del Cañón,' 'dentro del alcance del tiro de Cañon,' 'alcance del Tiro del Cañon de la Plaza,' in its various formulations. This phraseology took on a life of its own, to the extent that more than a decade 
later, it was still in use by Gómez's successors such as Dionisio Kelly, an Irish veteran of Spain's invasion of Portugal during the Seven Years' War. Incidentally, Kelly also became caught up in the next Anglo-Spanish conflict, the U.S. War of Independence, when he attempted to return to Spain from Manila aboard the Santa Inés in 1779 and was taken prisoner of war during its capture. ${ }^{29}$

In addition to foregrounding spatial arguments regarding the proximity of churches to the city walls, advocates of securitisation through architectural destruction also contended that there was danger in the material fabric of extramural churches, bridges, and, in the case of the Parián, other buildings made of stone. While la Torre described churches as 'extramural forts,' and censured the 'strength and outsized grandeur' of the Binondo complex, for example, his successor, Feliciano Márquez, seems to have suffered from a fear of masonry, reciting a list of all the stone and brick structures outside the walls - The Convent of Dilao, and Hospital of S. Lazaro, are large Buildings of Cut Stone situated 475 varas from the curtain of defence. They dominate the Bastions of San Lorenzo and San Andres'-and imagining the dangers they posed: the two stone bridges 'of Dilao and San Lazaro,' for instance, 'could serve as refuges for hidden Enemies.' Further, they proposed a material remedy to this material risk. De la Torre, for example, argued that, following the demolition of stone churches, new ones be built only in cane and straw-vernacular building materials which Spaniards had chosen on previous occasions to replace stone because of their flexibility during earthquakes, but whose advantage, from the perspective of the security panic, was that they were easily destroyed in case of attack. Or, as de la Torre put it, 'they burn, and do not impede defence.' While such a claim was not untrue in a strictly material sense, the assumptions it embedded (for example, that extramural buildings ought to burn easily) were also matters of judgment that were open to interpretation-interpretation that could have been based not only on the material or spatial characteristics of the city, but also on wider questions. For example, did the potential security risk of a precise repeat of the British breach outweigh the real cultural loss incurred by not rebuilding San Juan Bautista de Bagumbayan, which Concepción had described before the war as a 'refuge, and spiritual Comfort for' the 'variety of nations' who lived there? And, given the fierce, although unsuccessful, defence of Bagumbayan that its population had mounted-and given Anda's generalised success in pushing back the British in places outside the city walls by forging alliances that included religious such as Purificación and indigenous people-was a materialist strategy of fortifying the walled city and demolishing extramural 'forts' preferable to an alternative based on the improved use of human resources and alliances? ${ }^{30}$

This is not to say that the engineers envisioned preserving the dwellings and other buildings that were inhabited by the extramural towns' 'Yndios y Mestizos.' Rather, they viewed such architecture, made of cane [caña] and bamboo [nipa], as too disposable even to require representation: 'Note that this Plan does not designate the Islands of thatched houses surrounding the city,' wrote Gómez in the cartouche to the left of his 1764 plan, 'because the intention was only to show those of masonry, so that a clear understanding will arise of how damaging these buildings are, and of the need to demolish those within cannon shot, without which precaution the Plaza will always be lost whenever enemies lay siege. ${ }^{31}$

Once set in motion, the multifaceted process of securitisation through cartography, architecture, and engineering initiated by Gómez and de la Torre proceeded for another 
half-century-intensified, perhaps, by the tendency of Gómez's successors to disparage the state of the defences as they found them, and to put their own stamp on the ongoing work. Hence Márquez complained about the 'ruinous state' of the fort and the 'deplorable state' of the Plaza. And hence Kelly (who described the old counterscarp as 'defective to its situation') implemented the creation of an additional perimeter even beyond that proposed in Gómez's plan. In this, amplified project, Kelly created a sluice gate and breakwater that diverted the tide into a second, exterior moat [contrafoso], as well as another earthen barrier beyond it. ${ }^{32}$

While Gómez's successors may have expanded upon his plan, however, they generally worked within his cartographical and architectural template. Márquez's 1767 'Plan of the current state of the plaza of Manila and its surroundings and suburbs' also presented the city in his terms, rather than those articulated by Roxas. Thus while it continued to indicate many of the landmark buildings of the pre-war extramural landscape (notably, the Parish and Convent of the Parian [no. 18], the Convent and Parish of Dilao [no. 20], the Hospital of San Lázaro [no. 22], the 'ruined Convent of S. Juan de Bagumbaya' [no. 23] and the 'destroyed Parish of San Tiago [no. 24]'), it did not present the zones within which these buildings were situated as living townscapes or as elements of a dense built fabric-with the exception of the parish and convent of Parián, which it presented as densely built, if not inhabited. Rather, the 1767 plan presents the entire extramural corridor bounded by the Bay of Manila, the Calzada, and the Estero de San Lázaro (again with the exception of the Parián) as blank spaces, or spaces with a dotting of vegetation. Indeed, even more ominously than Gómez, Márquez wrote of these areas that 'In the adjoining Map I omit the houses of the Indians, which being of canes and bamboos (combustible material) form the Pueblos bordering the Churches of Hermita, Dilao, S. Miguel, S. Anton, the Parian, Santa Cruz, Binondoc, and Tondo drawn there. ${ }^{33}$

In this period, the process of razing those landmark buildings also began. Among the first casualties were the Santiago parish church and San Juan Bautista de Bagumbayan. In 1769 military officials removed them along with the town of Bagumbayan, leaving what Kelly approvingly called a 'cleared space' (Figure 4). This was repeated throughout the extramural corridor. Although Kelly grudgingly marked on his map that the similarly 'prejudicial suburb of the Parian' and its church still existed in 1775 along with the districts of San Miguel, Dilao, and San Lázaro, it too was cleared. This may be seen by referring to Thomas Sanz's 1783 'Plan showing works executed in the plaza of Manila in the years 1783 and preceding No. 2.' On this are specified both the 'demolished Houses of the Parian' $[\mathrm{H}]$ and a 'Bridge serving no purpose, which had to be destroyed' $[\mathrm{R}]$. In the latter case, this representation of the destruction of the bridge also effectively enacted a kind of 'destruction of memory,' in Robert Bevan's phrase (2006), seeing as the bridge, in fact, formerly had served a useful role: linking the inner portion of the Pueblo de Dilao (and the walled city itself) to the outer part of the town, to Dilao's Franciscan convent and church, and to the Pueblo de San Miguel. ${ }^{34}$

To be sure, these too would be demolished, as may be seen from a 1795 map by Gregorio Clavero in which all that remained of the Franciscan church at Dilao was a dotted outline and all traces removed of its companion building, the Hospital of San Lázaro. These institutions would be replaced by a new Hospital of San Lázaro (constructed north of the river on formerly Jesuit territory) and a new parish and pueblo of San 


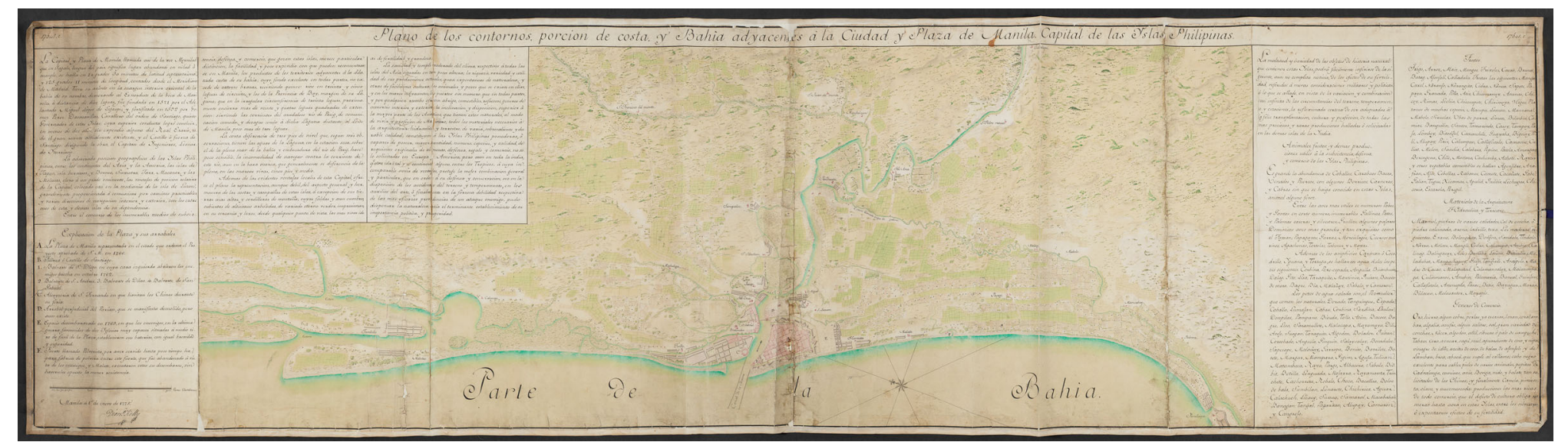

Figure 4. Dionisio Kelly, Plano de los contornos, porcion de costa, y Bahía adyacentes a la ciudad y Plaza de Manila, Capital de las Yslas Philipinas. Manuscript map on paper roll, 1775.

(c) British Library Board, Manuscripts Add. 17,641. 


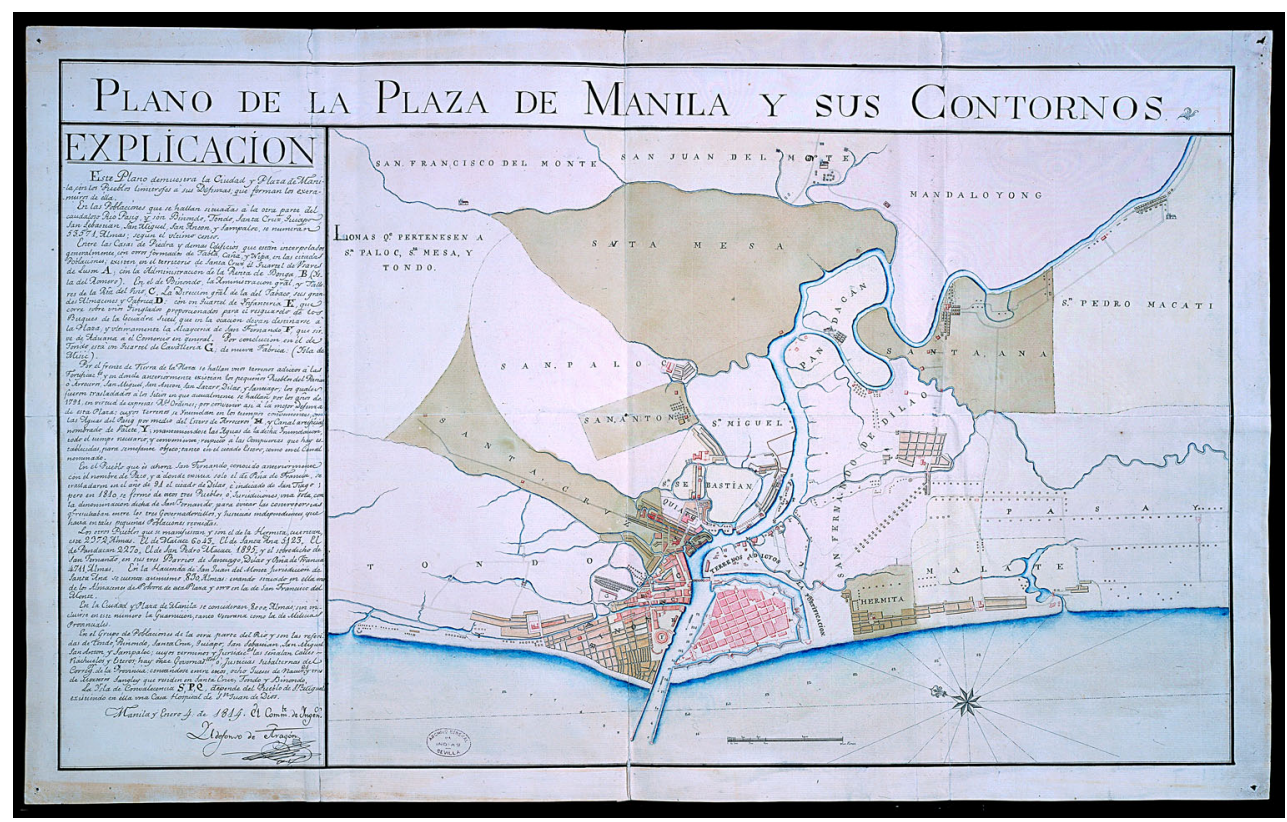

Figure 5. Ildefonso de Aragón, Plano de la plaza de Manila y sus contornos, 1814. Spain. Ministerio de Educación, Cultura y Deporte. Archivo General de Indias, AGI MP-FILIPINAS,133.

Fernando de Dilao, established farther inland, at modern-day Paco. Despite these replacements, however, the extramural world ceased to exist. By the opening of the nineteenth century, all that remained was a blank security crescent, fittingly described in an 1814 map as 'terrenos adictos a la fortificación' (Figure 5). ${ }^{35}$

Because so much more analysis has been devoted to trade than to war in the Pacific, it would be too soon to make any final conclusions on the relationships between eighteenthcentury Anglo-Spanish conflict and either economic or cultural change. There are many important subjects that this essay has not been able to consider: for instance, the roles played by local people in the breaking and remaking of Manila; or the responses of the city's inhabitants to its partitioning and to the processes that attended it, for instance the relocation and consolidation of extramural towns and parishes. How, for example, did the process of architectural destruction unleashed by the Seven Years' War transform social relationships in Manila, and the relationships between place, space, and memory? And, moving beyond the eighteenth century, it is possible to view the establishment of the security crescent not only as an act of destruction, but also as an act of creation-and to ask what kinds of meanings, memories, and relationships it generated in the final century of Spanish colonial rule. These are questions that future scholarship might consider. ${ }^{36}$

\section{Notes}

1. See, for instance, Berg 2004 and 2005; Brewer and Porter 1993; Goodman and Norberg 2007. This subject is addressed more fully in my forthcoming book, Art and War in the Pacific World.

2. This phrase is taken from the Omohundro Institute's conference, 'Contest for Continents: The Seven Years' War in Global Perspective,' 22-24 Oct. 2009. 
3. S[amue]l Cornish to Lord Anson, 1 Nov. 1762, copy in Hardwicke Papers, Vol. DL. Navy Papers, British Library (hereafter cited as BL) 35,898. Note that Cornish wrote this letter after both the capture of the city and the Santísima Trinidad.

4. 'A Description of the Philippine Islands, with account of their climate, natural productions, the navigation, etc.; compiled from Spanish authors and official papers by Admiral Sir Hyde Parker,' no date [before 1782], BL Add. Mss. 19,295, pp. 4, 12.

5. 'Relación de los sucesos acaecidos en la pasada Guerra de los Yngleses por lo perteneciente solamente al convento de Sta. Clara y sus religiosas en Manila,' 1764, Archivo Franciscano Ibero-Oriental (AFIO) 21/28.

6. Albemarle [George Keppel] to Bishop [Pedro Agustín Morell de Santa Cruz], 19 Oct. 1762, Huntington Library (hereafter HEH) PO 942; Parcero Torre 1998, 159. Interestingly, Syrett 1970 omits this correspondence.

7. Miguel Antonio Gómez to Julián de Arriaga, 29 July 1763, Archivo General de Indias (hereafter AGI) Filipinas, 922, N.5.

8. Calderón Henríquez to Dawsonne Drake and Council, no date [December 1762?], Papers concerning the Philippines and Penang 1762-1820, BL IOR/H/77. This copy is an East India Company translation; otherwise, unless noted, translations are the author's.

9. Francisco Javier de la Torre to Julián de Arriaga, 22 June 1764, AGI Filipinas, 922, N.2.

10. Draper's payment: 'Accounts,' in 'Memorandums for Fort Letters in 1763,' 10 Nov. 1762, BL IOR/E/4/862, [1030]. 'Pox': Draper to Richard Pierson, 18 Feb. 1759 (quoted in Dreaper 2006, 44; Manilla Hall, ibid., 124-27).

11. These intersections are also important to, but generally neglected within, the subsequent history of the British Empire. For example, Maya Jasanoff has emphasised how central the 'collecting' of Indian objects and manuscripts was to late-eighteenth-century British 'imperial selffashioning' in India- 'collecting' that included episodes of mass looting, notably in the British defeat of Tipu Sultan at the 1799 Siege of Seringapatam. Yet, Jasanoff presents both the relationships between war, surplus transfer, and identity at that moment, and the scale of the transfer at Seringapatam as unprecedented: 'Tipu's treasure,' she writes, 'amounted to $£ 1,143,216$ - easily the largest prize that had ever been taken by British arms' (Jasanoff 2004, 123-24). This surely overlooks the Havana-Manila expeditions, undertaken only a generation previously (and, in the latter case, launched from India) - and the fact that British takings in 1762 , adjusted for inflation, were identical to or exceeded those in Seringapatam.

12. BL Add. Mss. 22,975.

13. 'Relación de Fr. Joseph de la Concepción, Rector provincial de provincia de San Nicolas de Tolentino de las Islas Philipinas, del origen, progressos y estado de dicha provincia [...] desde el año de 1605 hasta el presente de 1751,' with maps by Francisco Alegre, BL Add. Mss. 13,973 . Note that BL records incorrectly read ' 1651 ' rather than ' 1751 .'

14. Cabrera Bueno, Navegacion especulativa, y practica [....]. Impresa en Manila en el Convento de Nuestra Señora de los Angeles de la Orden de Nro. Seraphico Padre San Francisco Año de 1734. 'A Description of the Philippine Islands [...] by Admiral Sir Hyde Parker,' BL Add. Mss. 19,295.

15. 'Luconia,' in manuscript atlas, 'To the Right Hon.able JOHN Lord SOMMERS Baron of EVESHAM Lord High CHANCELLOUR of ENGLAND \& c. [...] presented by [...] William Hacke,' 1700, BL Maps 7.Tab.125. Parker, 'A Description of the Philippine Islands.'

16. Parker, 'A Description of the Philippine Islands.' Cabrera Bueno, Navegacion especulativa, $y$ practica. This also contained derrotas, with Manila at the hub, detailing routes within east and southeast Asia such as the challenging (and, by Cabrera Bueno's time, forbidden) voyage between the Philippines and Japan, the Philippines-Macao route, and the Philippines-Cambodia route.

17. Parker, 'A Description of the Philippine Islands.' Admiral Sir Hyde Parker, 'A description of the coast from Cape Mendocino to Acapulco [California], by the Admiral Don Joseph Gonsalez Cabrera Bueno,' BL Add. Mss. 19,297. 'New Albion': see, for example, The American 
Gazetteer (London: Printed for A. Millar, and J. \& R. Tonson, 1762); this practice continued to the era of the U.S. War of Independence (itself an Anglo-Spanish conflict).

18. 'Authenticated abstract of thirty official journals of as many voyages from the Philippine Islands to New Spain, made in the years 1699-1740; from originals in the public archives in Manila; 22 Nov. 1742' [Pedro de Antioquía, 'Testimonio relativo de treinta diarios de la navegac[ió]n hecha por diferentes navios de la carera de Philipinas para Nueva España'], 1742, BL Add. Mss. 19,293; [Alexander Dalrymple], 'Extracts in English from the preceding paper,' BL Add. Mss. 19,294.

19. The American Gazetteer, no page (entry for 'ACA'). S[amue]l Cornish to Lord Anson, 1 Nov. 1762 , copy in BL Add. MS 35,898.

20. Miguel Antonio Gómez to Julián de Arriaga, 29 July 1763, AGI Filipinas, 922, N.5.

21. Henry Dundas, William Pitt and Edward James Eliot, 'Secret Dispatch to India, relative to an Expedition against Manila,' 9 Nov. 1796, in BL Add MS 12582, [24-27].

22. 'Relación de Fr. Joseph de la Concepción,' 85.

23. 'Relación de Fr. Joseph de la Concepción,' 85-86.

24. 'Relación de Fr. Joseph de la Concepción, 85-86.

25. Roque de la Purificación to King Carlos III, 20 July 1764, AFIO 22/88.

26. Francisco Javier de la Torre to Julián de Arriaga, 17 July 1764, AGI Filipinas, 922, N.5.

27. Miguel Antonio Gómez, 'Año de 1764. Testimonio del Plan formado en Virtud de Providencia Governativa del Estado en que se hallava esta plaza quando la tomaron los Ingleses y del que tenga el día de oy,' 17 July 1764. AGI Filipinas, 922, No. 5. Gómez, 'Plano de la plaza de Manila, capital de las Philipinas, y Archipiélago de San Lázaro. Va designado con lineas fuertes un nuevo proyecto de fortificaciones para poner dicha plaza en estado de defensa,' 12 July 1764, AGI MP-Filipinas, 160.

28. Gómez, 'Año de 1764. Testimonio del Plan;' Gómez, 'Explicación del Plano de la Plaza,' AGI Filipinas, 922, No. 5; and 'Plano de la plaza de Manila.'

29. Gómez, 'Año de 1764. Testimonio del Plan,' 'Explicación del Plano de la Plaza,' and 'Plano de la plaza de Manila'; de la Torre to Arriaga, 17 July 1764. See, for example, Dionisio Kelly, 'Plano de los contornos, porción de costa y bahia adyacentes á la ciudad y plaza de Manila, capital de las Yslas Philipinas,' 1775, BL Add. Mss. 17,641. C.

30. Feliciano Márquez, 'Relación del actual estado en que se halla la plaza de Manila y de sus circunstancias essenciales a ella anexas,' 30 Sept. 1767, AGI Filipinas,486; Torre to Arriaga, 17 July 1764.

31. Gómez, 'Plano de la plaza de Manila.'

32. Feliciano Márquez to Julián de Arriaga, 30 Sept. 1767, AGI Filipinas, 486. Dioniosio Kelly, 'Plano de una porcion de la Plaza de Manila,' 1 Jan. 1770, Newberry Library Ayer MS Map 315.

33. Feliciano Márquez, 'Plano del actual estado de la plaza de Manila y de sus contornos y arrabales,' 30 Sept. 1767, AGI MP-FILIPINAS,51BIS; Márquez, 'Relación del actual estado en que se halla la plaza de Manila.'

34. Thomas Sanz, 'Plano que manifiesta las obras executadas en la plaza de Manila en el año de 1783 y antecedentes $\mathrm{N}^{\circ}$ 2,' 31 May 1783, AGI MP-Filipinas, 120. Unlike in the cases explored by Bevan, however, here the destruction was not inflicted by external parties or during a civil war, but rather by a ruling administration in a post-conflict environment.

35. Gregorio Clavero, 'Plano de la plaza y contornos de Manila, capital de las yslas Filipinas, en el que se manifiestan las obras proyectadas y executadas con motivo de los actuales preparativos de guerra,' 23 Dec. 1795, AGI MP-Filipinas, 188.

36. For discussion in other contexts see Herscher 2010; Mancini and Breshanan 2015.

\section{Acknowledgement}

The author would like to thank The Paul Mellon Centre for Studies in British Art for providing a Research Support Grant. 


\section{Notes on contributor}

J. M. Mancini is Senior Lecturer in the Department of History, Maynooth University (Ireland). Her publications include Architecture and Armed Conflict (2015), edited with Keith Bresnahan; PreModernism: Art-World Change and American Culture from the Civil War to the Armory Show (2005), winner of the Smithsonian American Art Museum's 2008 Charles C. Eldredge Prize for Outstanding Scholarship in American Art; and essays in American Art, American Quarterly, Critical Inquiry, and other journals. Most recently, she published an essay on architecture, religion, and regime change in the Philippine-American War in the Companion to American Art, eds. Davis, Greenhill and LaFountain (2015). The research included here is part of her forthcoming book, Art and War in the Pacific World.

\section{References}

Berg, Maxine. 2004. In pursuit of luxury: Global history and British consumer goods in the eighteenth century. Past \& Present 182: 85-142.

- 2005. Luxury and pleasure in eighteenth-century Britain. Oxford: Oxford University Press. Brewer, John, and Roy Porter, eds. 1993. Consumption and the world of goods. London: Routledge. Bevan, Robert. 2006. The destruction of memory: Architecture at war. London: Reaktion.

Dreaper, James. 2006. Pitt's 'Gallant Conqueror': The turbulent life of Lieutenant General William Draper. London: I. B. Tauris.

García del Pino, César. 2002. Toma de La Habana por los ingleses y sus antecedentes. Havana: Editorial de Ciencias Sociales.

[Garnett, Oliver]. 2005. Melford Hall, Suffolk. Warrington: The National Trust.

Goodman, Dena, and Kathryn Norberg, eds. 2007. Furnishing the eighteenth century: What furniture can tell us about the European and American past. New York: Routledge.

Herscher, Andrew. 2010. Violence taking place: The architecture of the Kosovo conflict. Stanford: Stanford University Press.

Jasanoff, Maya. 2004. Collectors of empire: Objects, conquests and imperial self-fashioning. Past and Present 184: 109-35.

Laughton, J. K., revised by Nicholas Tracy. No date. Cornish, Sir Samuel, Baronet. In Oxford Dictionary of National Biography. http://www.oxforddnb.com/view/article/6334.

Leibsohn, Dana. 2014. 'Dentro y fuera de los muros': Manila, ethnicity, and colonial cartography. Ethnohistory 61 (2): 229-51.

Lysons, Daniel, and Samuel Lysons. 1908. Magna Brittania; being a concise topographical account of the several counties of Great Britain, vol. 1. London: Printed for T. Cadell and W. Davies in the Strand.

Mancini, J. M. 2011. Siege mentalities: objects in motion, British imperial expansion, and the Pacific turn. Winterthur Portfolio 45 (2/3): 125-40.

Mancini, J. M., and Keith Bresnahan, eds. 2015. Architecture and armed conflict: The politics of destruction. New York: Routledge.

Parcero Torre, Celia María. 1998. La pérdida de la Habana y las Reformas Borbónicas en Cuba. [Valladolid]: Junta de Castilla y León, Consejería de Educación y Cultura.

Rice, Geoffrey. 1980. Great Britain, the Manila ransom, and the 1766 Falklands Island dispute. The International History Review 2 (3): 386-409.

Syrett, David, ed. 1970. The siege and capture of Havana 1762. London: Navy Records Society.

Walter, Richard. 1928. Anson's voyage round the world. Edited by G. S. Laird Clowes. London: Martin Hopkinson Ltd.; Boston: Charles E. Lauriat Co. 